\title{
Source and site of action of anti-luteolytic interferon in red deer (Cervus elaphus): possible involvement of extra-ovarian oxytocin secretion in maternal recognition of pregnancy
}

\author{
D. R. J. Bainbridge ${ }^{1}$ and H. N. Jabbour ${ }^{2}$ \\ 'Zoological Society of London, Institute of Zoology, Regent's Park, London NW1 4RY, UK; and 'MRC Reproductive Biology Unit, \\ Centre for Reproductive Biology, 37 Chalmers Street, Edinburgh EH3 9EW, UK
}

\begin{abstract}
Six conceptuses were collected from red deer hinds on day 22 after synchronization of oestrus with intravaginal progesterone-releasing devices (removal of device $=$ day 0 ). Within $24 \mathrm{~h}$ of culture in vitro, the supernatant from five of six conceptuses showed detectable antiviral activity. Interferon $\alpha$ (IFN- $\alpha$ ) receptors were identified by immunohistochemistry on the luminal surface of the endometrium, in the neurohypophysis and paraventricular hypothalamus, but not in the ovaries of the hinds from which the conceptuses were collected. Another 16 intact hinds were synchronized as above. Injection of $4 \mathrm{mg}$ IFN i.m. twice a day on days 13-15 had no effect on cloprostenol-induced oxytocin secretion on day 15 and did not prevent cloprostenolinduced luteal regression. Sixteen ovariectomized hinds received a protocol of steroid treatment to mimic ovarian hormone secretion during the normal oestrous cycle. On day 16, hinds showed undulant oxytocin secretion that showed a degree of temporal association with uterine $\mathrm{PGF}_{2 \alpha}$ release. Treatment with $4 \mathrm{mg}$ IFN- $\alpha_{1} 1$ twice a day on days 13-16 had no effect on this spontaneous oxytocin secretion, but reduced the magnitude of cloprostenol-induced oxytocin secretion on day $17(P<0.05)$. These results indicate that red deer conceptuses secrete an anti-luteolytic IFN to which the endometrium expresses a receptor during early pregnancy. The presence of IFN receptors in the hypothalamus and posterior pituitary and the IFN-induced suppression of extra-ovarian oxytocin secretion provides tentative evidence of an involvement of the central nervous system in maternal recognition of pregnancy in deer.
\end{abstract}

\section{Introduction}

Successful establishment of pregnancy in eutherian mammals is dependent on maintenance of the progesteronesecreting corpus luteum (Flint et al., 1990). In polyoestrous mammals, the embyro or embryos must prevent the destruction of the corpus luteum at luteolysis, a process known as the maternal recognition of pregnancy (Short, 1969). In cattle and sheep, this is achieved by conceptus secretion of IFN- $\tau$, which reduces endometrial oxytocin sensitivity, suppresses pulsatile uterine $\mathrm{PGF}_{2 \alpha}$ secretion and thus prevents luteolysis (Bazer, 1992; Bazer et al., 1997). IFN- $\tau$ shows a high degree of homology with bovid $\alpha$ IFNs (Stewart $e t$ al., 1987) and both $\alpha$ and $\tau$ IFNs are thought to bind to the same receptor on the endometrium, the type 1 IFN receptor (Lim and Langer, 1993; Li and Roberts, 1994).

Recently, more information has been gained on the mechanisms underlying maternal recognition of pregnancy in another group of ruminants, the Cervidae. In red deer, natural luteolysis is associated with synchronous pulsatile

Revised manuscript received 30 November 1998. release of ovarian oxytocin and luteolytic $\mathrm{PGF}_{2 \alpha}$ (Bainbridge and Jabbour, 1997). Secretion of these hormones is thought to be mediated by a positive feedback loop between the uterus and the ovary (Flint et al., 1991, 1994), and this loop is activated at the end of the luteal phase by increasing endometrial oxytocin sensitivity that occurs under the control of ovarian steroids (Bainbridge et al., 1996a,b). However, the initiating factor of each individual pulse of luteolytic hormone release is unknown (Bainbridge and Jabbour, 1997).

There is considerable evidence that the conceptus antiluteolytic factor in red deer is also an IFN. Uterine flushings from pregnant red deer hinds show antiviral activity (Flint, 1995) and administration of exogenous IFN- $\alpha$ suppresses uterine oxytocin sensitivity, pulsatile secretion of oxytocin and PGF $_{2 a}$, and luteolysis itself (Bainbridge et al., 1996b; Bainbridge and Jabbour, 1997). However, certain aspects of the pregnancy recognition system in red deer remain to be elucidated. Firstly, IFN secretion by isolated red deer conceptuses has not been reported. Secondly, no receptors for IFN have been demonstrated in any reproductive tissue in red deer. Thirdly, the relative importance of local and systemic actions of conceptus IFN are unknown: although 
IFN- $\tau$ is thought to act locally within the uterus in bovids (Lamming et al., 1995), antiviral activity is also detectable in the uterine venous effluent of pregnant sheep (SchalueFrancis et al., 1991). No data have been published regarding the site of action of putative conceptus IFNs in deer.

The aim of this study was to elucidate the mechanisms underlying maternal recognition of pregnancy in red deer by investigating the source and site of action of the putative anti-luteolytic IFN. Red deer conceptuses were cultured in vitro and their IFN secretion was assessed. The distribution of IFN- $\alpha$ and IFN- $\tau$ receptors in female reproductive tissues was determined by immunohistochemistry and the effects of exogenous IFN on ovarian and non-ovarian oxytocin secretion were studied using intact and steroid-treated ovariectomized hinds.

\section{Materials and Methods}

\section{Animals}

Experiments 1 and 2 were conducted at ADAS Rosemaund Research Centre, Herefordshire, UK $\left(52^{\circ} 10^{\prime} \mathrm{N}\right)$ during the breeding season. Ten mature red deer hinds with a mean $( \pm \mathrm{SD}$ ) live weight of $93.2 \pm 8.2 \mathrm{~kg}$ were used. Experiments 3, 4 and 5 were conducted at the Institute of Zoology Laboratory at Whipsnade Wild Animal Park, Bedfordshire, UK $\left(51^{\circ} 50^{\prime} \mathrm{N}\right)$ in autumn 1995. In these experiments, 16 mature intact red deer hinds with a mean ( \pm SD) live weight of $99.5 \pm 5.2 \mathrm{~kg}$ and 16 mature ovariectomized red deer hinds with a mean $( \pm \mathrm{SD})$ live weight of $103.3 \pm 10.4 \mathrm{~kg}$ were used.

\section{Experiment 1: quantification of IFN secretion by red deer conceptuses}

Ten hinds were treated with two progesterone releasing intravaginal controlled internal drug releasing devices (CIDR type G, $0.3 \mathrm{~g}$ progesterone per device; Carter Holt Harvey Plastic Products, Hamilton). The first CIDR device was inserted for 8 days and was replaced with a second device for 5 days. All hinds were run with a fertile stag after removal of CIDR devices. Twenty-two days after removal of CIDR devices, all hinds were killed and the uterus removed within $5 \mathrm{~min}$. The uterus was separated from the vagina, oviducts and ovaries; the mesometrium was trimmed and the uterine body was bisected sagittally. A blunt needle was introduced into the proximal end of each uterine horn and the conceptus was flushed from the pregnant horn with $25 \mathrm{ml}$ Hepes-buffered medium 199 (Gibco BRL Life Technologies, Paisley).

The six conceptuses obtained (one conceptus from each of six hinds) were cultured for $24 \mathrm{~h}$ using a modified version of the technique described by Godkin et al. (1992). After three rinses in Hepes-buffered medium 199, each conceptus was placed in $30 \mathrm{ml}$ minimum essential medium with Earl's salts and glutamine (Gibco) with the addition of $0.2 \mathrm{iu}$ bovine insulin $\mathrm{ml}^{-1}, \quad 200 \mathrm{iu}$ penicillin $\mathrm{ml}^{-1}, 200 \mu \mathrm{g}$ streptomycin sulphate $\mathrm{ml}^{-1}$ (Sigma, Poole), $500 \mathrm{ng}$ amphotericin $\mathrm{B} \mathrm{ml}^{-1}$ (fungizone; Gibco) and $1 \%(\mathrm{v} / \mathrm{v})$ non-essential amino acid preparation (Gibco). The culture was maintained in an atmosphere of $50 \%$ nitrogen, $45 \%$ oxygen and $5 \%$ carbon dioxide at $38^{\circ} \mathrm{C}$. The cultures were then chilled on ice and centrifuged at $2000 \mathrm{~g}$ for $1 \mathrm{~h}$ at $4^{\circ} \mathrm{C}$. The supernatant was decanted and stored at $-20^{\circ} \mathrm{C}$ before the IFN assay. The pellet was stored at $-20^{\circ} \mathrm{C}$ before determination of nucleic acid content.

The IFN activity of the supernatant and an aliquot of medium aspirated after $5 \mathrm{~h}$ of culture was measured by the Madin-Darby bovine kidney cell-Semliki Forest virus cytopathic effect inhibition assay described by Abayasekara et al. (1995) and the sensitivity of this assay was $100 \mathrm{iu} \mathrm{ml}{ }^{-1}$. All samples were included in a single assay. A laboratory standard preparation of recombinant bovine IFN- $\alpha_{1} 1$ (rBoIFN- $\alpha_{1} 1$; CibaGeigy, Basle) was calibrated against a sample of the 1st international standard preparation of human IFN- $\alpha_{\mathrm{II}}$ (1987) and used for generating the standard curve in the assay.

Each conceptus pellet was lysed by agitation at $37^{\circ} \mathrm{C}$ for $24 \mathrm{~h}$ in a Tris-HCl buffered solution of sodium dodecyl sulphate ( $33 \mathrm{~g} \mathrm{l}^{-1}$; BDH Laboratory Supplies, Poole) and proteinase K (330 $\mathrm{g} \mathrm{I}^{-1}$; Sigma). Nucleic acid was extracted by serial equilibration over (i) phenol (BDH), (b) a $1: 1$ mixture of phenol and chloroform (BDH) and (c) chloroform. The spectrophotometric absorbance of the resulting aqueous phase at $260 \mathrm{~nm}$ was measured and used to calculate the concentration of nucleic acids in the solution.

\section{Experiment 2: histological localization of IFN receptors}

Localization of IFN receptors in red deer tissues was acheived by double-antibody fluorescence immunohistochemistry. The primary antibody (IFNRAC-abr; Research Diagnostics Inc., Flanders, NJ) was raised in rabbits against a recombinant fusion protein containing the cytoplasmic portion of subunit 1 of the human IFN- $\alpha$ receptor (IFN $\alpha$ R1).

Uterus, ovary, pituitary and hypothalamus tissue was collected from the pregnant hinds killed in Expt 1, frozen in polyethylene bags on dry ice and stored at $-70^{\circ} \mathrm{C}$. Tissues were cut into $7 \mu \mathrm{m}$ sections and transferred to glass slides coated with 3-aminopropyltriethoxy-silane (Sigma). After dehydration at $4^{\circ} \mathrm{C}$ for at least $2 \mathrm{~h}$, sections were fixed for $2 \mathrm{~min}$ in acetone.

Dilution buffer was made up as follows: $10 \mathrm{mmol}$ PBS $\mathrm{l}^{-1}$ ( $\mathrm{pH} 7.4$ ) with $10 \mathrm{~g} \mathrm{BSA} \mathrm{l}^{-1}, 10 \mathrm{~g}$ fish gelatin $\mathrm{l}^{-1}$ and $0.05 \%(\mathrm{v} / \mathrm{v}$ ) Tween-20 detergent (Sigma). A section from each tissue was incubated (i) for 30 min with normal goat serum (Dako A/S, Glostrup) diluted 1:30 in dilution buffer, (ii) for $1 \mathrm{~h}$ with $10 \mu \mathrm{g} \mathrm{ml}^{-1}$ primary antibody to IFN $\alpha \mathrm{R} 1$ in dilution buffer and (iii) for $1 \mathrm{~h}$ in the dark with $6.9 \mu \mathrm{g} \mathrm{ml}^{-1}$ affinity isolated fluorescein isothiocyanate (FITC)-conjugated goat antirabbit IgG (Sigma). Between each incubation the sections were washed in $10 \mathrm{mmol} \mathrm{PBS} \mathrm{l}^{-1}$ (pH 7.4) with $1 \mathrm{~g} \mathrm{BSA} \mathrm{l}^{-1}$, and after the last incubation the sections were mounted in Citifluor (UKC, Canterbury) and viewed under ultraviolet light. Sections were then re-stained using a conventional haematoxylin technique. In each tissue, an adjacent section was treated in the same way except the anti-IFN $\alpha$ R1 
antibody was replaced by normal rabbit serum (Gibco) diluted 1:1000 in dilution buffer.

\section{Experiment 3: effect of exogenous IFN on luteal function}

The antiviral activity of the $\mathrm{rBoIFN}-\alpha_{\mathrm{I}} 1$ preparation was measured by the Madin-Darby bovine kidney cell-Semliki Forest virus cytopathic effect inhibition assay described by Abayasekara et al. (1995) and was found to be $1.32 \times 10^{8} \mathrm{iu}$ $\mathrm{mg}^{-1}$ protein.

A total of 16 hinds were allocated to one of two treatment groups ( $n=8$ per group) adjusted for live weight. Each hind was treated with two CIDR devices as described in Expt 1 $($ removal of device $=$ day 0$)$. Group 1 received no further treatment and served as controls. Group 2 received i.m. injections of $4 \mathrm{mg} \mathrm{rBoIFN}-\alpha_{1} 1$ in $1.6 \mathrm{ml}$ sterile water twice a day from day 13 to day 15 .

Hinds received a single cloprostenol challenge on day 15 . A dose of $500 \mu \mathrm{g}$ of the $\mathrm{PGF}_{2 \alpha}$ analogue cloprostenol $(2 \mathrm{ml}$ Estrumate; Pitman-Moore Ltd, Crewe) was injected into the middle gluteal muscle. Jugular blood samples $(5 \mathrm{ml})$ were collected 48 and $24 \mathrm{~h}$ before and $0,6,12,18,24,36,48,60$ and $72 \mathrm{~h}$ after the cloprostenol injection, and plasma progesterone concentrations were analysed. In addition, blood samples $(10 \mathrm{ml})$ were collected 30,20 and $10 \mathrm{~min}$ before and 5, 10, 20, 30 and $40 \mathrm{~min}$ after the cloprostenol injection and plasma oxytocin concentrations were analysed.

\section{Experiment 4: endogenous oxytocin and $P G F_{2 u}$ secretion in ovariectomized hinds}

Six ovariectomized hinds received a treatment regimen known to induce plasma progesterone profiles and temporal changes in uterine oxytocin sensitivity similar to those of intact cyclic hinds (Bainbridge et al., 1996b). Each hind was treated with two CIDR devices as described in Expt 1 (removal of device $=$ day 0 ). After removal of the first CIDR device, all hinds underwent a programme of steroid treatment as follows: i.m. injection of $50 \mu \mathrm{g}$ oestradiol benzoate (Sigma Chemical Company, St Louis, MO) in peanut oil at -24 and $-12 \mathrm{~h} ; 100 \mu \mathrm{g}$ oestradiol benzoate at 0 , $12,24,36 \mathrm{~h}$; insertion of two successive CIDR devices from day 3 to day $18 ; 50 \mu g$ oestradiol benzoate twice a day on day 18 .

Blood samples $(10 \mathrm{ml})$ were collected at intervals of $1 \mathrm{~h}$ for $16 \mathrm{~h}$ on days $4,10,16$ and 18 , and the samples were divided into two aliquots before storage at $-20^{\circ} \mathrm{C}$. One aliquot was used for determination of concentrations of oxytocin and the other aliquot for determination of 13,14-dihydro-15-keto prostaglandin $\mathrm{F}_{2 \alpha}$ (PGFM), the pulmonary metabolite of prostaglandin $\mathrm{F}_{2 \alpha}$.

\section{Experiment 5: effect of exogenous IFN on extra-ovarian oxytocin secretion}

Ten ovariectomized hinds were allocated to one of two treatment groups ( $n=5$ per group) adjusted for live weight and all hinds received the steroid treatment described in Expt 4 . Group 1 received no further treatment and served as controls. Group 2 received i.m. injections of $4 \mathrm{mg}$ rBoIFN- $\alpha_{1} 1$ in $1.6 \mathrm{ml}$ sterile water twice a day from day 13 to day 16 .

On day 16 , jugular blood samples $(10 \mathrm{ml})$ were collected from all hinds at $1 \mathrm{~h}$ intervals for $16 \mathrm{~h}$. On day 17, all hinds received a single $500 \mu \mathrm{g}$ cloprostenol challenge as described in Expt 3. Blood samples $(10 \mathrm{ml})$ were collected 30, 20 and $10 \mathrm{~min}$ before and 5, 10, 20, 30 and $40 \mathrm{~min}$ after the cloprostenol injection. All plasma samples harvested were analysed for oxytocin concentration.

\section{Radioimmunoassays}

Plasma progesterone concentrations were measured in duplicate using a radioimmunoassay validated for red deer (Argo and Loudon, 1992). The interassay coefficients of variation $(\mathrm{CV})$ for red deer control samples with mean concentrations of $1.20,0.43$ and $0.095 \mathrm{ng} \mathrm{ml}^{-1}$ were $9.2,9.0$ and $20.1 \%$, respectively, and the intra-assay $\mathrm{CV}$ were $4.2,5.8$ and $10.1 \%$, respectively. The sensitivity of the assay was $0.033 \mathrm{ng}$ $\mathrm{ml}^{-1}$ (defined as sample concentration corresponding to the mean minus twice the standard deviation of the total binding).

Plasma oxytocin concentrations were measured in duplicate using a radioimmunoassay method validated for red deer (Bainbridge and Jabbour, 1997). The interassay CV for red deer control samples with mean concentrations of 33.0, 6.84 and $2.33 \mathrm{ng} \mathrm{ml}^{-1}$ were $8.8,11.0$ and $16.2 \%$, respectively, and the intra-assay CV were $4.1,7.2$ and $9.2 \%$, respectively. Assay sensitivity (as defined above) was $0.4 \mathrm{ng} \mathrm{ml}^{-1}$.

Plasma concentrations of PGFM were measured in duplicate using a radioimmunoassay method validated for red deer (Bainbridge et al., 1996a). The interassay CV for controls with mean concentrations of 340.0 and $60.2 \mathrm{pg} \mathrm{ml}^{-1}$ were 12.8 and $12.3 \%$, respectively, and the intra-assay CV were 10.3 and $8.1 \%$, respectively. The sensitivity of the assay (defined earlier) was $30 \mathrm{pg} \mathrm{ml}^{-1}$.

\section{Statistical analyses}

In Expt 1, the relationship between IFN production and nucleic acid content was investigated by linear regression. In Expts 3 and 5, the effects of IFN treatment on endocrine parameters were analysed by least squares regression analysis. In Expt 4, endogenous hormone secretion was analysed as described by Bainbridge and Jabbour (1997). A pulse of hormone secretion was defined as a time point when the plasma hormone concentration exceeded the mean $+2 \times \mathrm{SD}$ for that hind. Data were analysed by the chi-squared test (number of hinds showing synchronous episodes of hormone secretion).

\section{Results}

\section{Experiment 1: quantification of IFN secretion by red deer conceptuses}

Conceptuses collected on day 22 after removal of CIDR devices (approximately 20 days after oestrus) showed the 
Table 1. Interferon secreted by red deer conceptuses cultured in vitro

Interferon produced by conceptus (units)/ nucleic acid content (mg)

\begin{tabular}{lcc}
\cline { 2 - 3 } Conceptus & After 5 h culture & After 24 h culture \\
\hline 1 & 516 & 1893 \\
2 & $<186$ & 1261 \\
3 & 1870 & 7312 \\
4 & $<180$ & $<180$ \\
5 & 2728 & 4333 \\
6 & 718 & 2156 \\
\hline
\end{tabular}

gross appearance of late filamentous blastocysts. Detectable amounts of IFN were secreted by four of six conceptuses after culture in vitro for $5 \mathrm{~h}$, and by five of six conceptuses after $24 \mathrm{~h}$. At both time points, the inter-conceptus variation in IFN production was high (Table 1). There was a positive association between IFN production within $5 \mathrm{~h}$ and the nucleic acid content of the conceptus $\left(n=6, r^{2}=0.844, P<0.01\right)$, although this was not true of IFN production after $24 \mathrm{~h}$ in culture $\left(n=6, r^{2}=0.427, P>0.05\right)$.

\section{Experiment 2: histological localization of IFN receptors}

The intercaruncular endometrium was formed into multiple fronds of epithelial cells constituting a complex luminal surface. FITC fluorescence was apparent at the luminal surface of these fronds throughout the intercaruncular areas (Fig. $1 \mathrm{a}-\mathrm{c}$ ). The uterine caruncles consisted largely of connective tissue and blood vessels and contained less epithelial tissue, although this showed FITC fluorescence (Fig. 1d-f). The caruncles also contained strongly autofluorescent granules, possibly fibrous or elastic material. The ovary showed little specific FITC binding in either luteal or follicular tissue (Fig. 1g-i). The posterior pituitary showed scattered focal areas of FITC fluorescence (Fig. $1 \mathrm{j}-\mathrm{l}$ ), as did the paraventricular region of the hypothalamus (Fig. 1m-o).

\section{Experiment 3: effect of exogenous IFN on luteal function}

There was no significant effect of IFN treatment on plasma oxytocin secretion either before or after cloprostenol challenge $(P>0.1$, Fig. 2a). There was no effect of IFN treatment on plasma concentrations of progesterone before cloprostenol challenge $(P>0.1$, Fig. 2 b). Plasma progesterone concentrations were lower in IFN-treated hinds than in control hinds $6 \mathrm{~h}$ after cloprostenol administration $(P<0.05)$ and were higher in IFN-treated hinds than in control hinds 24,32 and $72 \mathrm{~h}$ after cloprostenol treatment (all $P<0.05$ ).

\section{Experiment 4: endogenous oxytocin and $P G F_{2 n}$ secretion in ovariectomized hinds}

Individual oxytocin and PGFM profiles of the six hinds on day 16 are shown (Fig. 3). On day 16, hinds showed low amplitude undulant secretion of oxytocin. A greater proportion of hinds showed synchronous pulses of oxytocin and PGFM on day 16 than on days 4,10 and 18 (3/6 versus $0 / 6,0 / 6,0 / 6 ; P<0.05)$. Two hinds also showed apparently asynchronous pulses of PGFM secretion.

\section{Experiment 5: effect of exogenous IFN on extra-ovarian oxytocin secretion}

There was no significant effect of IFN treatment on the mean or variance of plasma oxytocin concentrations in ovariectomized hinds on day $16(P>0.1, P>0.1$, Fig. $4 a)$ or on the mean oxytocin concentrations on day 17 before cloprostenol challenge $(P>0.1$, Fig. 4 b). Plasma oxytocin concentrations increased after administration of cloprostenol $(P<0.00001)$ on day 17. Oxytocin concentrations were lower in the IFN-treated group than in the control group at 20, 30 and $40 \mathrm{~min}$ after cloprostenol treatment (all $P<0.002$ ).

\section{Discussion}

The results from Expt 1 of the present study are the first to demonstrate that the IFN activity present in the uterus of pregnant red deer (Flint, 1995) is secreted by the conceptus. Indeed, Bird et al. (1997) reported that the red deer conceptus contained IFN transcripts. It is proposed that the function of the conceptus IFN is to prevent luteolysis, since administration of exogenous IFN- $\alpha$ to red deer is known to suppress uterine oxytocin sensitivity, inhibit pulsatile secretion of oxytocin and $\mathrm{PGF}_{2 \alpha}$, and delay luteolysis (Bainbridge et al., 1996b; Bainbridge and Jabbour, 1997). The class of the cervid IFN is not distinguished by antiviral assay, although cloning and sequencing of the genes encoding the peptide will elucidate any similarities to bovid $\alpha, \beta$ and $\tau$ IFNs. There is little information on cervid IFNs, although a gene similar to ovine IFN- $\tau$ has been detected in the white-tailed deer by hybridization of genomic DNA with a probe generated to ovine IFN- $\tau$ (Leaman and Roberts, 1992).

Although previous studies have investigated ruminant endometrial IFN receptors (Godkin et al., 1984; Li and Roberts, 1994), Expt 2 represents the first histological

Fig. 1. Sections of red deer tissues stained to detect the presence of IFN receptors. Three plates are presented for each tissue: (i) a section incubated with anti-IFN receptor rabbit IgG followed by fluorescein isothiocyanate (FITC)-conjugated anti-rabbit antibody; (ii) a negative control slide incubated with normal rabbit serum and FITC-conjugated anti-rabbit antibody; and (iii) the first section (i) stained with haematoxylin and photographed under bright-field microscopy. The tissues presented are $(a-c)$ intercaruncular endometrium, $(d-f)$ uterine caruncle, (g-i) ovary, with follicular antrum on the left and luteal tissue on the right, $(j-1)$ neurohypophysis, and (m-o) hypothalamus in the region of the left paraventricular nucleus, with the third cerebral ventricle on the right. Scale bar represents $50 \mu \mathrm{m}$. 

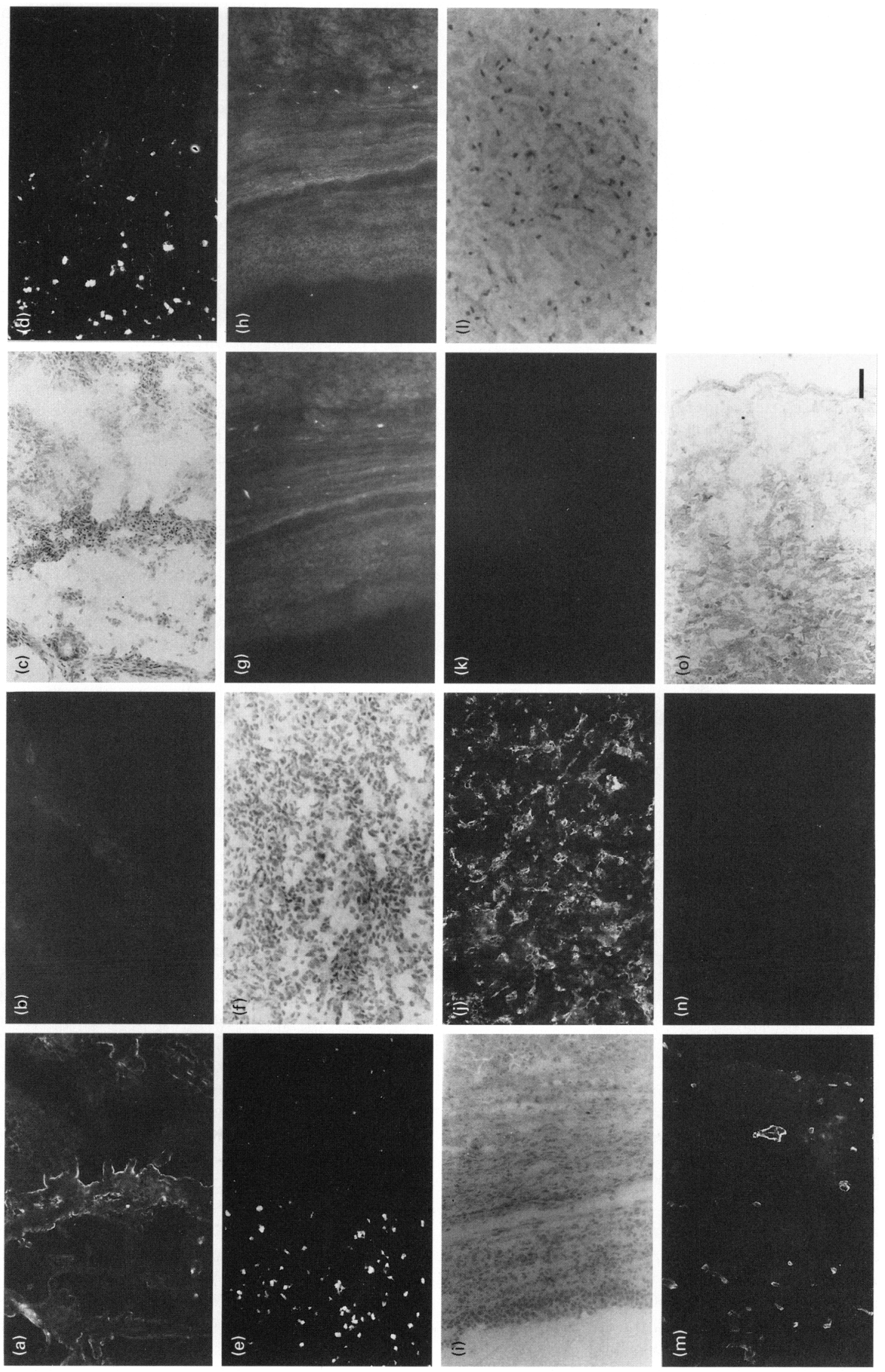

D. 


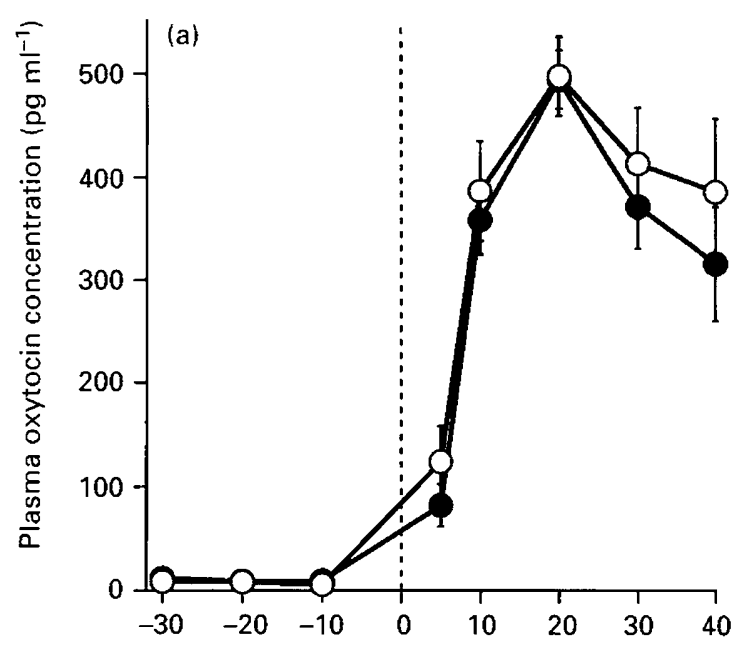

Time from cloprostenol administration (min)

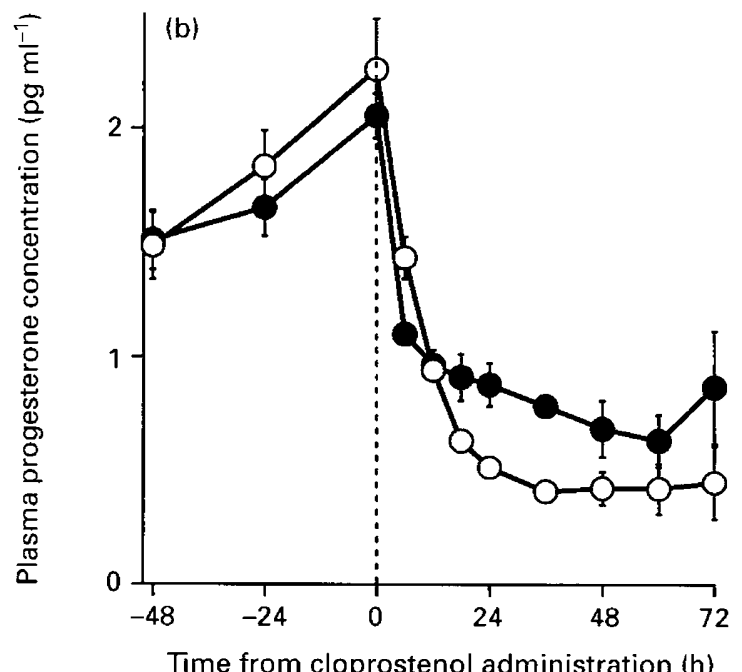

Fig. 2. Effect of an i.m. injection of $500 \mu \mathrm{g}$ cloprostenol on plasma concentrations of (a) oxytocin and (b) progesterone in intact hinds, 15 days after removal of controlled internal drug releasing (CIDR) devices. (O) control hinds; $(O)$ hinds treated twice a day with i.m. injections of $4 \mathrm{mg}$ recombinant bovine IFN- $\alpha_{1} 1$ on days $13-15$ after removal of CIDR devices ( $n=6$ in each group). Values are mean \pm SD.

localization of such receptors. The major subunit (IFN $\alpha$ R1) of human, murine and bovine IFN $-\alpha$ and IFN- $\tau$ receptors spans the cell membrane, binds the ligand and is responsible for signal transduction (Uzé et al., 1990). The amino acid sequences of bovine and human IFN $\alpha$ R1 share $68 \%$ homology, and the cytoplasmic domains are particularly homologous (Lim and Langer, 1993).

In the present study, the IFN $\alpha$ R1 staining identified on the convoluted luminal surface of the intercaruncular endometrium presumably represents the primary binding site of the conceptus IFN, presenting a large area for IFN binding in direct apposition to the conceptus. The presence of IFN receptors on the endometrium may explain the marked suppressive effect of exogenous IFNs on uterine oxytocin sensitivity (Bainbridge et al., 1996b) and pulsatile $\mathrm{PGF}_{2 \alpha}$ secretion in red deer (Bainbridge and Jabbour, 1997). It is likely that the smaller amount of staining in the caruncular tissue reflects the specialized fibro-vascular nature of these fetal adhesion zones, which do not undergo the same degree of epithelial proliferation as the intercaruncular areas during early pregnancy. The low IFN receptor expression in the corpus luteum may explain why exogenous IFN did not exert a direct luteoprotective effect by suppressing the luteolytic effects of prostaglandin or prostaglandin-induced secretion of oxytocin in Expt 3. Similarly, the lack of IFN receptors on follicular cells in red deer hinds probably precludes the follicle as a site of action of anti-luteolytic IFNs.

The physiological relevance of the IFN receptors detected in the central nervous system is uncertain. Both the paraventricular region and the posterior pituitary of red deer were notable for expression of IFN- $\alpha \mathrm{R} 1$ and this raises the possibility that conceptus IFNs may act at a site other than the endometrium. This proposal remains speculative, since the physiological reason for such a dual-site suppression of luteolysis by inhibition of both uterine $\mathrm{PGF}_{2 \alpha}$ release and pituitary oxytocin secretion is unknown, and such a system has not been identified in any other species. In addition, IFN receptors may have a non-reproductive function in the central nervous system. However, pituitary oxytocin secretion has been postulated as the initiating factor in the synchronous episodes of oxytocin and $\mathrm{PGF}_{2 \mathrm{x}}$ occurring at luteolysis in both sheep (McCracken et al., 1996) and red deer (Bainbridge and Jabbour, 1996b). Thus, modulation of such secretion by conceptus IFNs may reflect a secondary mechanism of maternal recognition of pregnancy in some species.

The results from Expt 3 indicate that IFN has no physiologically significant direct anti-luteolytic effect on the corpus luteum. Prostaglandin-induced oxytocin secretion in intact hinds during the late luteal phase was unaffected by IFN treatment. Treatment with IFN had a biphasic effect on progesterone secretion after injection of cloprostenol, but did not avert luteolysis. At $6 \mathrm{~h}$ after injection of cloprostenol, progesterone secretion in IFN-treated hinds was lower than that in control hinds, and this effect may be similar to the IFN-induced transient decrease reported in cattle (Plante et al., 1991). After 24-72 h, progesterone concentrations were higher in IFN-treated hinds than in control hinds. Cloprostenol is thought to exert its primary luteolytic effect by acting directly on the corpus luteum (Sheldrick and Flint, 1985), but may exert a minor indirect luteolytic effect by inducing luteal secretion of oxytocin, which, in turn, stimulates release of uterine $\mathrm{PGF}_{2 \alpha}$. Although cloprostenol induced luteal oxytocin release in IFN-treated hinds, such oxytocin would have a markedly suppressed $\mathrm{PGF}_{2 \alpha}-$ releasing effect on the desensitized endometrium. Thus, the smaller decrease in luteal progesterone secretion observed after IFN administration may be explained by an abrogation of a minor indirect luteolytic effect of cloprostenol.

Oxytocin secretion in ovariectomized hinds in Expt 4 was undulant and did not show the high amplitude peaks detected in intact hinds at luteolysis (Bainbridge and Jabbour, 1997). This observation indicates that the corpus luteum is the major source of oxytocin at luteolysis. The red 


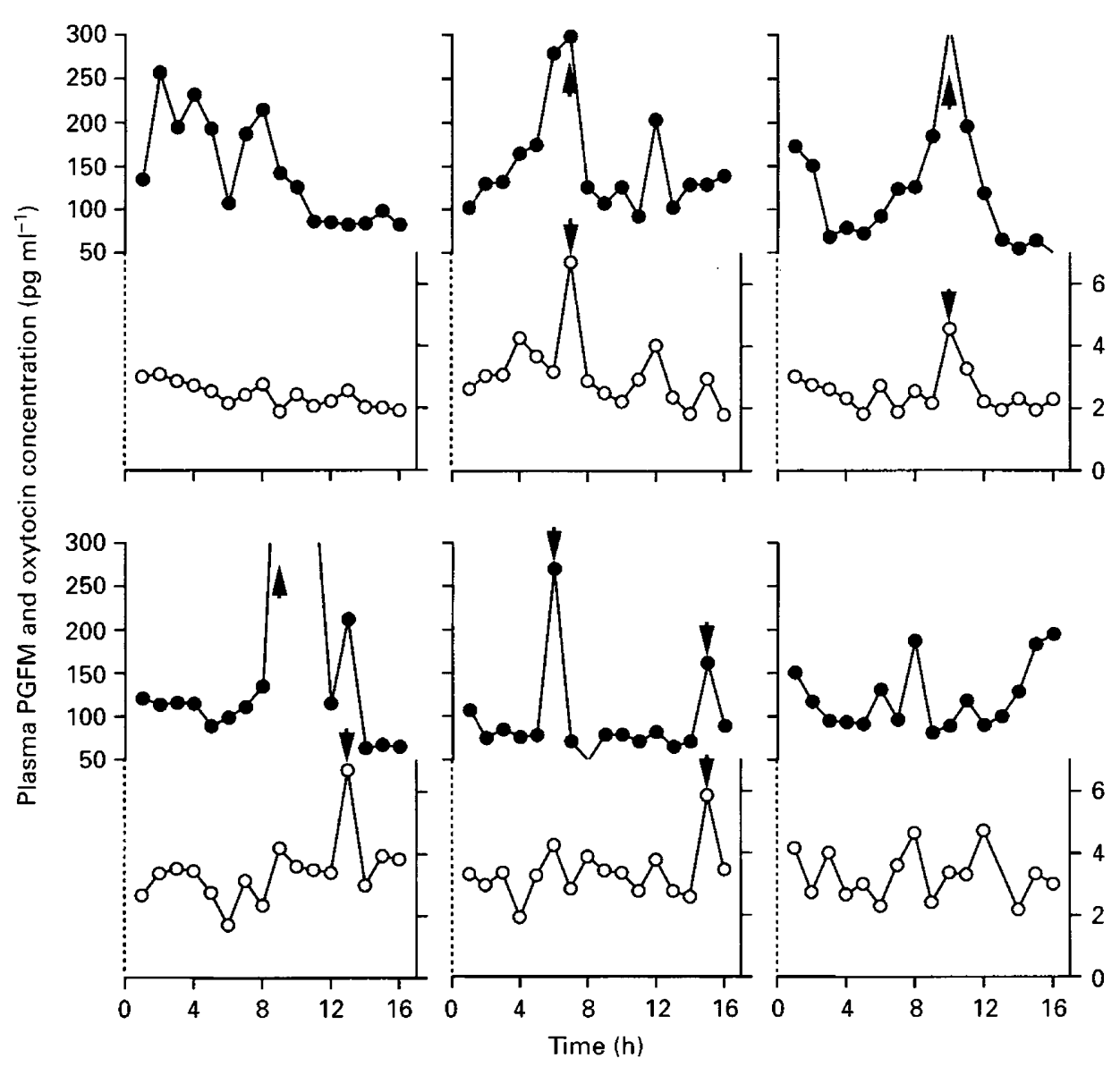

Fig. 3. Plasma concentrations of 13,14-dihydro-15-keto prostaglandin $F_{2 \alpha}$ (PGFM, ) and oxytocin (O) in individual steroid-treated ovariectomized hinds (group $2, n=8$ ) sampled at $1 \mathrm{~h}$ intervals for $16 \mathrm{~h}$ on day 16. Arrows show episodes of secretion when the plasma hormone concentration was greater than the mean $+2 \times$ SD for individual hinds.

deer uterus contains too little oxytocin to be a source of appreciable amounts of the hormone $\left(0.4-17.5 \mathrm{pg} \mathrm{g}^{-1}\right.$ wet weight at the time of luteolysis; D. R. J. Bainbridge and H. N. Jabbour, unpublished) and it is suggested that the posterior pituitary is a likely extra-ovarian source of undulant oxytocin secretion. Secretion of oxytocin and $\mathrm{PGF}_{2 \alpha}$ showed a degree of temporal association on day 16, indicating that the endometrium can respond in vivo to the non-ovarian oxytocin. This raises the possibility that the pituitary plays a role in pulsatile luteolytic hormone release, possibly as the initiating factor of individual pulses.

The cloprostenol-induced oxytocin secretion detected in ovariectomized hinds in Expt 5 represents a major endocrine difference between red deer and sheep, since ovariectomized ewes do not show such a response (Flint and Sheldrick, 1983). The physiological role of such prostaglandin-induced extra-ovarian oxytocin secretion is unclear, since the corpus luteum is thought to be the source of most oxytocin secreted at luteolysis in red deer (Flint et al., 1991; Bainbridge et al., 1996b). However, the present finding that extra-ovarian oxytocin secretion is sensitive to $\mathrm{PGF}_{2 \alpha}$ analogues supports the hypothesis that an oxytocin-secreting tissue other than the ovary, possibly the pituitary, is involved in the endocrine control of luteolysis. If there is an interaction between uterine PGF $_{2 \alpha}$ and pituitary oxytocin secretion in vivo, pulmonary $\mathrm{PGF}_{2 \alpha}$ metabolism must be less complete in red deer than in some other mammals (Piper et al., 1970) to allow PGF ${ }_{2 \alpha}$ to reach the central nervous system. The efficiency of metabolism of $\mathrm{PGF}_{2 x}$ in the lungs varies considerably between ungulate species: for example, approximately $99 \%$ of plasma $\mathrm{PGF}_{2 \alpha}$ is inactivated on a single pass through the pulmonary vasculature of sheep, whereas the corresponding value in pigs is $18 \%$ (David et al., 1980). An alternative explanation is that PGFM, rather than $\mathrm{PGF}_{2 \alpha^{\prime}}$ stimulates extra-ovarian oxytocin secretion in red deer.

Although ovariectomized hinds lack luteal tissue, the magnitude of cloprostenol-induced oxytocin secretion was similar in intact hinds in Expt 3 and ovariectomized hinds in Expt 5. It is possible that this similarity reflects the nonphysiological nature of cloprostenol administration, which may stimulate oxytocin release over a different time course from that of an endogenous pulse of $\mathrm{PGF}_{2 \alpha}$, and which is known to exhaust luteal stores of oxytocin in red deer (Flint et al., 1991). If extra-ovarian secretion is not exhausted in this way, this may explain why cloprostenol induces similar oxytocin secretion in intact and ovariectomized hinds, even 

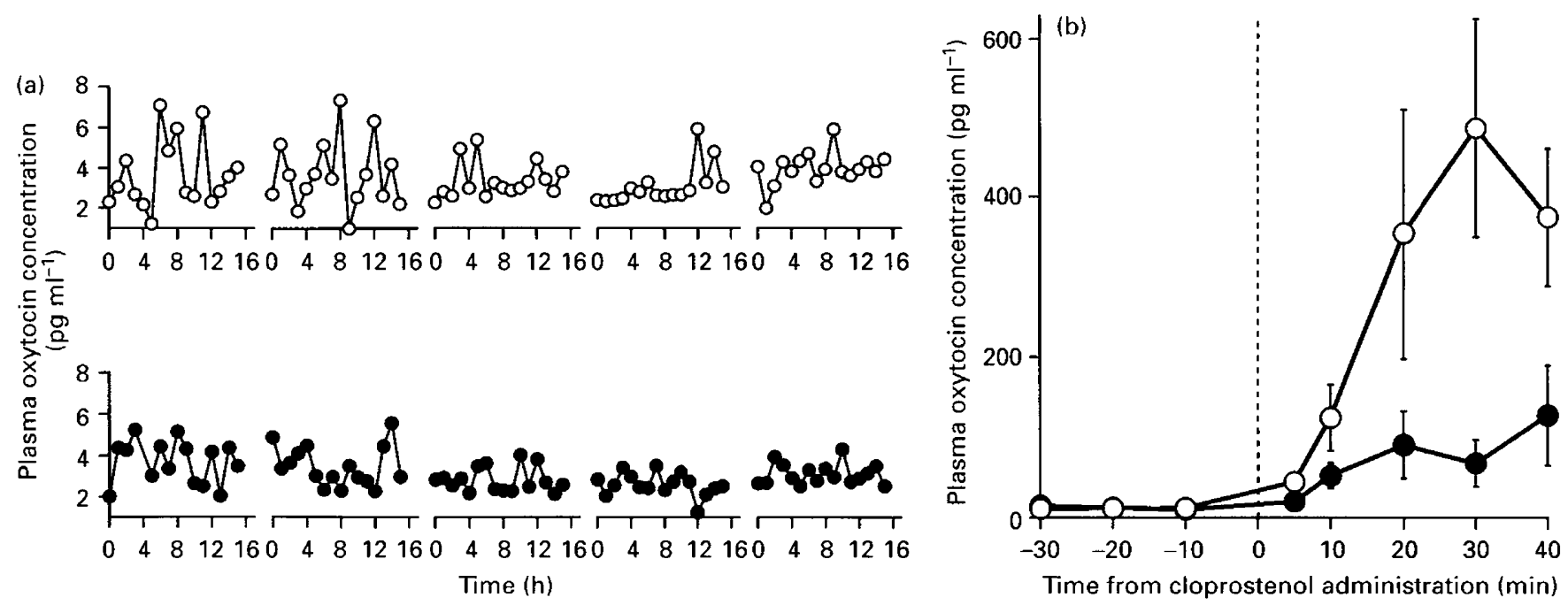

Fig. 4. Secretion of oxytocin in steroid-treated ovariectomized hinds (a) during blood sampling at $1 \mathrm{~h}$ intervals on day 16 after removal of controlled internal drug releasing (CIDR) devices and (b) after an i.m. injection of $500 \mu \mathrm{g}$ cloprostenol on day 17 . (O) control hinds; $(0)$ hinds treated twice a day with i.m. injections of $4 \mathrm{mg}$ recombinant bovine IFN- $\alpha_{1} 1$ on days $13-16$ after removal of CIDR devices ( $n=5 \mathrm{in}$ each group). Values in (b) are mean \pm SD.

though luteal secretion may exceed non-ovarian secretion at normal luteolysis. A second explanation for the similarity is that pituitary oxytocin secretion may be abnormally increased in ovariectomized hinds: ablation of luteal oxytocin secretion may reduce an inhibitory feedback effect of circulating oxytocin on the pituitary.

Cloprostenol-induced extra-ovarian oxytocin secretion was reduced by administration of exogenous IFN- $\alpha$. In addition to the immunohistochemical detection of IFN receptors in the posterior pituitary and paraventricular hypothalamus, this finding also indicates that central oxytocin-secreting neurones may be a secondary site of action of conceptus anti-luteolysins. Such an effect of IFNs would require transport of IFN from the uterine lumen to the brain, and it is not known whether this occurs in red deer. Schalue-Francis et al. (1991) detected IFN in the venous effluent of pregnant ewes, although whether IFN- $\tau$ can subsequently cross the blood-brain barrier remains to be determined.

The present study extends current understanding of maternal recognition of pregnancy in red deer. The red deer conceptus secretes an IFN, and the endometrium and the paraventricular nucleus and neurohypophyseal unit express the type I IFN receptor. These results may explain why exogenous IFN suppresses uterine oxytocin sensitivity, delays luteal regression (Bainbridge et al., 1996b) and inhibits cloprostenol-induced extra-ovarian oxytocin secretion, but has little direct effect on luteal secretion of oxytocin. The results also raise the possibility that red deer conceptus IFNs suppress luteolysis by acting at two sites to reduce pituitary oxytocin secretion as well as suppress uterine oxytocin sensitivity.

The authors would like to thank Caroline Layram, Andrew Hartley, David Deakin and Michelle Mohan for their assistance with animal handling and management, Mary-Jo Searle and Robert
Abayasekara for their help with the antiviral assay, and Patricia Lovell for her immunohistochemistry advice. The laboratory standard preparation of recombinant bovine IFN $\alpha_{1} 1$ (rBolFN- $\left.\alpha, 1\right)$ was donated by Rolf Steiger, Ciba-Geigy, Basle, Switzerland. This work was funded by a project grant from the Ministry of Agriculture, Fisheries and Food (CSA 2536). D. R. J. Bainbridge was supported by a Biotechnology and Biological Sciences Research Council Veterinary Postgraduate Fellowship (VRF37).

\section{References}

Abayasekara DRE, Sheldrick EL, Flick-Smith HC and Flint APF (1995) Role of protein kinase $C$ in the inhibitory action of trophoblast interferons on expression of the oxytocin receptor in sheep endometrium Endocrine 3 $151-158$

Argo CMcG and Loudon ASI (1992) Effect of age and time of day on the timing of the surge in luteinizing hormone, behavioural oestrus and mating in red deer hinds (Cervus elaphus) Journal of Reproduction and Fertility 96 $667-672$

Bainbridge DRJ and Jabbour HN (1997) Synchronous pulsatile release of oxytocin and prostaglandin $F_{2 x}$ occurs at luteolysis and is suppressed by pregnancy and exogenous interferon in red deer (Cervus elaphus) Journal of Reproduction and Fertilify 111 299-307

Bainbridge DRJ, Hunter MG, Chapple DG, Flint APF and Jabbour HN (1996a) Role of estrogen and prostaglandin $F_{2 \alpha s}$ in premature luteal regression in monovulatory and superovulated red deer (Cervus elaphus) Biology of Reproduction 54 347-354

Bainbridge DRJ, Davies M, Scaramuzzi RJ and Jabbour HN (1996b) Systemic administration of recombinant bovine interferon- $\alpha 1$ during the luteal phase delays luteal regression in red deer hinds (Cervus elaphus) Biology of Reproduction 55 883-888

Bazer FW (1992) Mediators of maternal recognition of pregnancy in mammals Proceedings of the Society for Experimental Biology and Medicine 199 373-384

Bazer FW, Spencer TE and Ott TL (1997) Interferon tau: a novel pregnancy recognition signal Americal fournal of Reproductive Immunology 37 412-420

Bird KJ, Jabbour HN, Kaluz S and Flint APF (1997) Maternal recognition of pregnancy in the red deer, Cervus elaphus. Journal of Reproduction and Fertility Abstract Series 19 Abstract 120

Davis AJ, Fleet IR, Harrison FA and Maule Walker FM (1980) Pulmonary metabolism of $\mathrm{PGF}_{2 v}$ in the conscious nonpregnant ewe and sow Journal of Physiology $30186 \mathrm{P}$ 
Flint APF (1995) Interferon, the oxytocin receptor and the maternal recognition of pregnancy in ruminants and non-ruminants: a comparative approach Reproduction, Fertility and Development 7313-318

Flint APF and Sheldrick EL (1983) Evidence for a systemic role for ovarian oxytocin in luteal regression in sheep Journal of Reproduction and Fertility 67 215-222

Flint APF, Hearn JP and Michael AE (1990) The maternal recognition of pregnancy in mammals fournal of Zoology 221 327-341

Flint APF, Sheldrick EL, McCann TJ, Brinklow BR and Loudon ASI (1991) Prostaglandin-induced secretion of oxytocin and prolactin in red (Cervus elaphus) and Père David's (Elaphurus davidianus) deer hinds: evidence for oxytocin of luteal origin General and Comparative Endocrinology 83 432-438

Flint APF, Jabbour HN and Loudon ASI (1994) Oxytocin stimulates uterine prostaglandin $\mathrm{F}_{2 \alpha}$ secretion in red deer (Cerous elaphus) Reproduction, Fertility and Development $6269-271$

Godkin JD, Bazer FW, Moffatt RJ, Sessions F and Roberts RM (1992) Purification and properties of a major, low molecular weight protein released by the trophoblast of sheep blastocysts at day 13-21 Journal of Reproduction and Fertility 65 141-150

Godkin JD, Bazer FW and Roberts RM (1984) Ovine trophoblast protein 1, an early secreted blastocyst protein, binds specifically to uterine endometrium and affects protein synthesis Endocrinology 114 120-130

Lamming GE, Wathes DC, Flint APF, Payne JH, Stevenson KR and Vallet JL (1995) Local action of trophoblast interferons in suppression of the development of oxytocin and oestradiol receptors in ovine endometrium Journal of Reproduction and Fertility 105 165-175

Leaman DW and Roberts RM (1992) Genes for the trophoblast interferons in sheep, goat and musk ox and distribution of related genes among mammals fournal of Interferon Research 12 1-11
Li J and Roberts RM (1994) Interferon- $\tau$ and interferon- $\alpha$ interact with the same receptor in bovine endometrium Journal of Biological Chemistry 26913 $544-13550$

Lim J-K and Langer JA (1993) Cloning and characterization of a bovine alpha interferon receptor Biochimica et Biophysica Acta 1173 314-319

McCracken JA, Custer EE, Eldering JA and Robinson AG (1996) The central oxytocin pulse generator: a pacemaker for the ovarian cycle Acta Neurobiologiae Experimentalis 56 819-832

Piper PJ, Vane JR and Wyllie JH (1970) Inactivation of prostaglandins by the lungs Nature $225600-604$

Plante C, Hansen PJ, Martinod S, Siegenthaler B and Thatcher WW (1991) Alteration of oestrous cycle length, ovarian function and oxytocininduced release of prostaglandin $F 2 \alpha$ by intruterine and intramuscular administration of recombinant bovine interferon- $\alpha$ to cows Journal of Reproduction and Fertility 93 375-384

Schalue-Francis TK, Farin PW, Cross JC, Keisler D and Roberts RM (1991) Effect of injected bovine interferon- $\alpha_{1} 1$ on oestrous cycle length and pregnancy success in sheep Journal of Reproduction and Fertility 91 347-356

Sheldrick EL and Flint APF (1985) Endocrine control of uterine oxytocin receptors in the ewe Journal of Endocrinology 106 249-258

Short RV (1969) Implantation and maternal recognition of pregnancy Ciba Foundation Symposium 111 2-26

Stewart HJ, McCann SHE, Barker PJ, Lee KE, Lamming GE and Flint APF (1987) Interferon sequence homology and receptor binding activity of ovine trophoblast antiluteolytic proteins Journal of Endocrinology 115 R13-R15

Uzé G, Lutfalla G and Gresser I (1990) Genetic transfer of a functional human interferon- $\alpha$ receptor into mouse cells: cloning and characterization Cell 60 225-234 